\title{
The relationship between P2X4 and P2X7: a physiologically important interaction?
}

\author{
Eilidh Craigie $^{1 *}{ }^{*}$ Rebecca E. Birch ${ }^{2}$, Robert J. Unwin ${ }^{1 \dagger}$ and Scott S. Wildman ${ }^{2 * t}$ \\ ${ }^{1}$ Centre for Nephrology, UCL Medical School, University College London, London, UK \\ 2 Urinary System Physiology Unit, Medway School of Pharmacy, Universities of Kent and Greenwich at Medway, Kent, UK
}

\section{Edited by:}

Bellamkonda K. Kishore, Univ. of

Utah Health Sciences \& VA Medical

Centers, USA

\section{Reviewed by:}

Oleh Pochynyuk, University of Texas Health Science Center at Houston, USA

Carolyn M. Ecelbarger, Georgetown University, USA

Annette Nicke, Max Planck Institute for Experimental Medicine,

Germany

\section{*Correspondence:}

Eilidh Craigie, Centre for

Nephrology, UCL Medical School

Royal Free Campus, Rowland Hill

Street, London, NW3 2PF, UK

e-mail:e.craigie@ucl.ac.uk;

Scott S. Wildman, Medway School of Pharmacy, The Universities of

Kent and Greenwich at Medway,

Anson Building, Central Avenue,

Chatham Maritime, Kent, ME4 4TB,

UK

e-mail: s.s.wildman@kent.ac.uk

${ }^{\dagger}$ Joint senior authors.
Purinergic signaling within the kidney is becoming an important focus in the study of renal health and disease. The effectors of ATP signaling, the P2Y and P2X receptors, are expressed to varying extents in and along the nephron. There are many studies demonstrating the importance of the $\mathrm{P}_{2} \mathrm{Y}_{2}$ receptor on kidney function, and other $\mathrm{P} 2$ receptors are now emerging as participants in renal regulation. The P2X4 receptor has been linked to epithelial sodium transport in the nephron and expression levels of the P2X7 receptor are up-regulated in certain pathophysiological states. P2X7 antagonism has been shown to ameliorate rodent models of DOCA salt-induced hypertension and P2X4 null mice are hypertensive. Interestingly, polymorphisms in the genetic loci of P2X4 and P2X7 have been linked to blood pressure variation in human studies. In addition to the increasing evidence linking these two P2X receptors to renal function and health, a number of studies link the two receptors in terms of physical associations between their subunits, demonstrated both in vitro and in vivo. This review will analyze the current literature regarding interactions between $\mathrm{P} 2 \mathrm{X} 4$ and $\mathrm{P} 2 \mathrm{X} 7$ and assess the potential impact of these with respect to renal function.

Keywords: purinergic, kidney, P2X4, P2X7, receptor

\section{INTRODUCTION}

ATP is an important extracellular signaling molecule that is the principal agonist for two different types of purinergic receptors: P2Y (G protein-coupled receptors) and P2X (non-selective ion channels). Eight different subtypes have been identified for P2Y $(1,2,4,6,11-14)$ and seven for P2X (1-7), and both P2Y and P2X receptors are found in virtually all mammalian tissues and participate in many different physiological processes [for recent reviews refer to (von Kugelgen and Harden, 2011) and (Surprenant and North, 2009)].

Purinergic signaling within the kidney is emerging as an important focus in the study of renal health and disease, and $\mathrm{P} 2 \mathrm{X}$ and $\mathrm{P} 2 \mathrm{Y}$ receptors are expressed to varying extents along the nephron; some are more ubiquitously expressed than others, and some alter their expression levels depending on the physiological and pathophysiological state of the kidney (for recent reviews covering P2 receptors in the kidney refer to (Vallon, 2008; Praetorius and Leipziger, 2010; Booth et al., 2012). There are numerous studies comprehensively demonstrating the importance of the $\mathrm{P}_{2} \mathrm{Y}_{2}$ receptor on kidney function (Vallon and Rieg, 2011), but P2X receptors are also beginning to emerge as important participants in kidney homeostasis (Bailey et al., 2012).

The recent success in obtaining the first $\mathrm{x}$-ray crystallography structure of a P2X receptor (Kawate et al., 2009) verified previous evidence that functional P2X receptors are composed of three subunits (Nicke et al., 1998; Barrera et al., 2005). All subunits (except for P2X6) assemble to form homotrimeric receptors, and some can be assembled in various configurations to form heterotrimeric P2X receptors (Torres et al., 1999; North, 2002) which display unique pharmacological profiles compared with homotrimers (Lewis et al., 1995; King et al., 2000). P2X7 is distinctive, as in the extensive heterotrimer study by Torres et al. it was the only P2X subunit found not to interact with others to form heterotrimers (Torres et al., 1999); however subsequent studies, as discussed in detail below, have suggested that this subunit may in fact be capable of interacting with other subunits. The amino acid (aa) sequence of $\mathrm{P} 2 \mathrm{X} 7$ is considerably longer than all other P2X subunits due to an extended cytoplasmic tail (595 aa vs. 388-471 aa for P2X1-6) and this is reflected in a larger protein mass $(\mathrm{P} 2 \mathrm{X} 1-6=43.4-51.7 \mathrm{KDa}, \mathrm{P} 2 \mathrm{X} 7=68.6 \mathrm{KDa})$. The $\mathrm{P} 2 \mathrm{X} 7$ receptor also possesses a significantly lower affinity for ATP than all other P2X receptors $\left[\mathrm{EC}_{50}=1-10 \mu \mathrm{M}\right.$ for P2X1-6 vs. $>100 \mu \mathrm{M}$ for P2X7 (North and Surprenant, 2000)].

The P2X subunit with which $\mathrm{P} 2 \mathrm{X} 7$ shares most similarity is P2X4; they are the most closely related of all $\mathrm{P} 2 \mathrm{X}$ in terms of aa sequence $(48.6 \%$ similarity for human sequence and $49.8 \%$ for rat), their chromosomal location (only $24 \mathrm{~Kb}$ apart on human chromosome 12), and their overlap in tissue 
distribution, particularly in immune, endothelial, and epithelial cells (Soto et al., 1996; Murrell-Lagnado and Qureshi, 2008). Given the similarities between these two receptors, researchers have sought to identify if there is a physical and functional interaction between them. Recent reports suggest a close interaction between P2X 4 and P2X7, although whether subunits assemble to form functional heterotrimers or interact as homotrimeric receptors to form cooperative receptor complexes is still unclear. We have reviewed the recent literature on the emerging relationship between P2X4 and P2X7, and focus on the potential role of these two receptors in kidney function.

\section{P2X4 AND P2X7 INTERACTIONS}

Evidence from an alveolar cell line suggests that P2X4 and P2X7 receptors can influence the expression of one another; P2X4 receptor expression is up-regulated when $\mathrm{P} 2 \mathrm{X} 7$ receptor expression is knocked down, and $\mathrm{P} 2 \mathrm{X} 7$ receptor expression is increased when P2X4 receptor expression is decreased (Weinhold et al., 2010). The authors also report alterations in the cellular localization of both receptors during their altered expression profiles, with plasma membrane expression becoming more pronounced in both instances.

Prolonged activation of some $\mathrm{P} 2 \mathrm{X}$ receptors can induce formation of non-selective pores that are permeable to large molecules, including fluorescent dyes (North, 2002; Pelegrin, 2011). It was previously believed that channel to pore formation was a unique property of the $\mathrm{P} 2 \mathrm{X} 7$ receptor, however, many studies now provide evidence that other subunits can also participate in pore formation e.g., P2X2 and P2X4 (Virginio et al., 1999), P2X4, $\mathrm{P} 2 \mathrm{X} 2$ and P2X2/3 heterotrimeric complexes (Khakh et al., 1999), and P2X2/5 heterotrimeric complexes (Compan et al., 2012). The potential for interactions between P2X4 and P2X7 to influence pore formation was explored using a HEK-293 heterologous expression system where co-expression induced an altered response to ATP and fluorescent dye uptake compared with expression of P2X7 alone (Casas-Pruneda et al., 2009). This study provides evidence supporting a functional interaction between $\mathrm{P} 2 \mathrm{X} 4$ and P2X7, although it was unable to ascertain the precise mechanism of this interaction; see Figure 1 for a schematic representation of possible mechanisms.
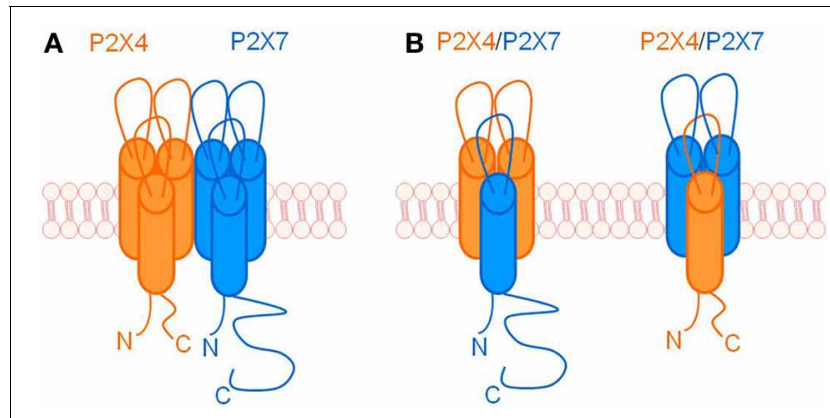

FIGURE 1 | Schematic representation of ways in which P2X4 and P2X7 may interact. (A) Individual P2X4 and P2X7 homotrimers physically associating with one another, possibly via C-terminal tail interactions or intermediate scaffolding proteins. (B) P2X4 and P2X7 subunits forming heterotrimeric receptors.
The $\mathrm{P} 2 \mathrm{X}_{\text {cilia }}$ channel receptor is an unidentified $\mathrm{P} 2 \mathrm{X}$ receptor expressed in airway ciliated cells; unidentified in that its pharmacology differs from all other previously described P2X homoor heterotrimers (Korngreen et al., 1998; Ma et al., 1999). Ma et al. presented evidence to suggest that $\mathrm{P} 2 \mathrm{X}_{\text {cilia }}$ may consist of both P2X4 and P2X7 subunits (Ma et al., 2006), demonstrating that the $\mathrm{P} 2 \mathrm{X}_{\text {cilia }}$ receptor shares properties in common with $\mathrm{P} 2 \mathrm{X} 4$ and $\mathrm{P} 2 \mathrm{X} 7$ homotrimers and showing positive immuno-staining for $\mathrm{P} 2 \mathrm{X} 4$ in the basal cilia where $\mathrm{P} 2 \mathrm{X}_{\text {cilia }}$ is expressed. However, the immuno-staining for $\mathrm{P} 2 \mathrm{X} 7$ at this location was incomplete and the study was inconclusive as to whether the $\mathrm{P} 2 \mathrm{X}_{\text {cilia }}$ receptor channel is a P2X4 and P2X7 heterotrimer. Guo et al. subsequently proposed that $\mathrm{P} 2 \mathrm{X} 4$ and $\mathrm{P} 2 \mathrm{X} 7$ subunits can form functional heterotrimers (Guo et al., 2007). Using a HEK-293 cell heterologous expression system they demonstrated that the surface expression of P2X4 increased more than 2-fold when it was co-expressed with P2X7 and that the subunits physically interacted using immunoprecipitation methods; they were also able to demonstrate that this interaction occurs in native tissue, specifically macrophages. In addition, studies using non-functional mutant P2X4 subunits in the Xenopus oocyte heterologous expression system revealed that when they were co-expressed alongside normal P2X7 subunits, the pharmacology of P2X7 receptors was altered. These demonstrations of both physical and functional interactions between $\mathrm{P} 2 \mathrm{X} 4$ and $\mathrm{P} 2 \mathrm{X} 7$ subunits prompted the authors to suggest that this was evidence for a heterotrimeric assembly.

Subsequent analyses of endogenous P2X4 and P2X7 interactions have indicated a preference for the formation of separate homotrimers that have a close physical interaction, rather than heterotrimers (Nicke, 2008; Boumechache et al., 2009). Chemical cross-linking analysis was used by Antonio et al. in a transfected cell line to show that although P2X4 and P2X7 are in close proximity to each other, no heterotrimeric receptors were formed (Antonio et al., 2011). In addition, atomic force microscopy imaging confirmed that receptor dimers were present and, although the identification of specific homotrimers was not possible, this, along with the results of the close proximity assay, supports the hypothesis that $\mathrm{P} 2 \mathrm{X} 4$ and $\mathrm{P} 2 \mathrm{X} 7$ homotrimers interact. However, what do these interactions mean for the function of P2X4 and P2X7? A study by Casas-Pruneda et al. shows that P2X4 and $\mathrm{P} 2 \mathrm{X} 7$ receptors functionally interact in both a heterologous system (HEK-293 cells) and native epithelia (mouse parotid acinar cells), and that they work together to produce an ATP-activated inward current with functional and pharmacological characteristics that are distinct from either individual homotrimer (CasasPruneda et al., 2009). Functional interactions between P2X4 and $\mathrm{P} 2 \mathrm{X} 7$ have also been demonstrated in mouse immune cells; normal P2X7 receptor-dependent functions (e.g., P2X7-mediated cell death and release of inflammatory signals) are altered when P2X4 expression levels are reduced (Kawano et al., 2012a,b; Sakaki et al., 2013). The current literature suggests that P2X4 and P2X7 are involved in functionally relevant interactions, both in native and transfected systems, and that the most likely explanation for their close relationship is that they are behaving in a cooperative manner as separate, but physically interacting, homotrimeric receptors. 


\section{PURINERGIC SIGNALING IN THE KIDNEY}

All of the key elements of the purinergic signaling system are found within the kidney, including $\mathrm{P} 2$ receptors, adenosine receptors, and a range of different ectonucleotidases [for recent review of renal ectonucleotidases see (Shirley et al., 2009)]. In addition, renal tubular cells are capable of releasing nucleotides in response to stimuli such as mechanical stimulation (e.g., stretch, increased flow rate, and osmotic swelling), local acidosis, hypoxia, and various hormones (e.g., vasopressin and aldosterone) (Vekaria et al., 2006; Odgaard et al., 2009). This accumulated evidence suggests a role for nucleotides in regulating renal function.

Functionally, P2 receptors have been shown to have important regulatory effects upon the kidney e.g., P2X1 receptor expression in the afferent arteriole of the glomerulus has been established to have a role in renal blood flow autoregulation (Inscho et al., 2004). With regards to epithelial transport, there are many studies demonstrating the importance of the $\mathrm{P}_{2} \mathrm{Y}_{2}$ receptor in the kidney and physiological studies using the $\mathrm{P}_{2} \mathrm{Y}_{2}$ null mouse model $\left(\mathrm{P} 2 \mathrm{Y}_{2}^{-/-}\right)$have been instrumental in these [for recent overview see (Vallon and Rieg, 2011)]. In the distal nephron $\mathrm{P}_{2} \mathrm{Y}_{2}$ receptor activation has been shown to mediate the inhibitory effect of both dietary sodium and aldosterone escape upon epithelial sodium channel (ENaC)-mediated sodium reabsorption (Pochynyuk et al., 2010; Stockand et al., 2010). Additionally, $\mathrm{P} 2 \mathrm{Y}_{2}^{-/-}$mice have a reduced ability to down regulate $\mathrm{ENaC}$ activity in response to nucleotide signaling and this is thought to contribute toward their hypertensive phenotype (Pochynyuk et al., 2008). In the thick ascending limb (TAL), $\mathrm{P} 2 \mathrm{Y}_{2}^{-/-}$mice have a greater expression of the sodium potassium chloride co-transporter type 2 (NKCC2) and increased furosemide-induced natriuresis, compared with control mice (Rieg et al., 2007; Zhang et al., 2011).

P2X4 and P2X7 are also expressed in the kidney, and genetically modified knockout mice exist for both, enabling researchers to investigate their involvement in the physiology and pathophysiology of tissues of expression, including the kidney. Some of these, along with in vitro studies investigating $\mathrm{P} 2 \mathrm{X} 4$ and $\mathrm{P} 2 \mathrm{X} 7$, will be discussed, with particular emphasis on renal function.

\section{RENAL P2X4}

P2X4 is expressed throughout the kidney (Schwiebert and Kishore, 2001; Turner et al., 2003), and many of the cell-based studies investigating renal $\mathrm{P} 2 \mathrm{X} 4$ have focused on its potential to influence epithelial sodium transport. McCoy et al. used a mousederived collecting duct (CD) cell line to show that activation of apical P2X, as well as $\mathrm{P} 2 \mathrm{Y}$, receptors had inhibitory effects on ENaC activity; they showed that these cells express P2X4 mRNA (McCoy et al., 1999). This suggested a possible link between $\mathrm{P} 2 \mathrm{X}$ receptor activation (tentatively $\mathrm{P} 2 \mathrm{X} 4$ ) and $\mathrm{ENaC}$ activity. Following on from this, Gorelik et al. used a Xenopus-derived renal epithelial cell line to show that activation of unspecified P2 receptors at the basolateral membrane induced changes in cell structure that altered the surface of the apical membrane in a way that permitted $\mathrm{ENaC}$ to become more active (Gorelik et al., 2005). The researchers built on this using a series of P2 receptor agonists and antagonists to show that the effects were most likely P2X4-dependent, and suggested that apical stimulation of
P2X receptors has an inhibitory effect up on $\mathrm{ENaC}$, while basolateral stimulation is potentiating (Zhang et al., 2007). In an oocyte heterologous expression system we demonstrated that P2X4 activation was able to inhibit $\mathrm{ENaC}$ currents due to a decrease in $\mathrm{ENaC}$ surface expression, demonstrating direct apical regulation of ENaC by a P2X receptor (Wildman et al., 2005). Together, these studies suggested a possible role for $\mathrm{P} 2 \mathrm{X} 4$ in renal sodium transport, in particular via $\mathrm{ENaC}$, and that there may be opposing actions for apical vs. basolateral activation. This was subsequently corroborated in native tissue using micro-dissected rat CDs; CDs were split-open and whole-cell patch-clamp electrophysiology was performed on the accessible apical membrane (Wildman et al., 2008). Using specific $\mathrm{P} 2$ receptor agonists these experiments showed that a P2X receptor was able to inhibit ENaC activity when the sodium concentration of the experimental bathing fluid was $145 \mathrm{mM}$ (standard conditions for these experiments). This $\mathrm{P} 2 \mathrm{X}$ receptor was thought to be a $\mathrm{P} 2 \mathrm{X} 4 / 6$ heterotrimer, given the localization of these two receptors, and taking in to consideration the earlier work of Torres and colleagues (Torres et al., 1999). However, in retrospect, there is the possibility of a P2X4 and P2X7 heterotrimer and/or homotrimer interaction. When the sodium concentration of the bathing solution was reduced to $50 \mathrm{mM}$ [more representative of distal tubular fluid sodium concentration (Malnic et al., 1966)], we saw a shift from inhibition to potentiation of ENaC activity by P2X 4 activation. We also showed robust expression of the $\mathrm{P} 2 \mathrm{X} 4$ receptor at both the apical and basolateral membranes of rat CDs using immunofluorescence. These observations led us to suggest that $\mathrm{P} 2 \mathrm{X} 4$ receptors may be capable of responding to the sodium concentration of distal tubular fluid to influence $\mathrm{ENaC}$ activity at a local level, and assist the kidneys in maintaining sodium balance.

Most studies published to date using the P2X4 null ( $\left.\mathrm{P} 2 \mathrm{X} 4^{-/-}\right)$ mouse model have not concerned renal function, and have focused predominantly on the receptor's role in pain, inflammation, and synaptic signaling (Sim et al., 2006; Brone et al., 2007; Tsuda et al., 2009; Ulmann et al., 2010). Interestingly, P2X4-/mice are hypertensive and a study investigating this linked it to endothelial dysfunction and impaired vasodilation (Yamamoto et al., 2006). Renal function was not investigated in this study and so the contribution of lack of P2X4 in the kidney to hypertension is unknown; this possibility should not be discounted, since almost all forms of inheritable hyper- and hypotension identified in humans have evidence of abnormal renal sodium handling (Lifton et al., 2001). Moreover, in a recent series of isolated perfused tubule experiments, Marques et al. demonstrated that $\mathrm{P} 2 \mathrm{X} 4^{-/-}$mice had a blunted response to ATP-mediated inhibition of sodium reabsorption in micro-dissected TALs (Marques et al., 2012). This shows a direct effect of P2X4 on epithelial sodium transport in native tissue, and indicates that these $\mathrm{P} 2 \mathrm{X} 4^{-/-}$mice have enhanced renal sodium reabsorption which may contribute toward their hypertension.

\section{RENAL P2X7}

$\mathrm{P} 2 \mathrm{X} 7$ is constitutively expressed in the majority of immune cells and receptor activation has broad pro-inflammatory effects. Consequently, the P2X7 null ( $\left.\mathrm{P} 2 \mathrm{X} 7^{-/-}\right)$mouse model has been extensively used to study inflammation in renal pathophysiology, 
and expression patterns of P2X7 have been mapped in models of inflammation. A major theme of these studies is that P2X7 expression is up-regulated in diseased/inflamed renal tissue, and that a lack of expression, such as in $\mathrm{P} 2 \mathrm{X} 7^{-/-}$mice, offers varying degrees of protection. For example, the induction of unilateral ureteric obstruction is a widely used model of early inflammation and tubulointerstitial fibrosis with progressive kidney injury; this is attenuated in $\mathrm{P} 2 \times 7^{-/-}$mice, which show less fibrosis, as well as reduced macrophage infiltration and expression of inflammatory cytokines (Goncalves et al., 2006). A key role for P2X7 in glomerulonephritis was also identified using rodent models of nephrotoxic nephritis in $\mathrm{P} 2 \mathrm{X} 7^{-/-}$mice (Turner et al., 2007) and after pharmacological inhibition of P2X7 in rats (Taylor et al., 2009). Moreover, P2X7 expression is up-regulated in the glomerulus and tubular cells in human lupus nephritis, a condition in which glomerular inflammation is an important feature (Turner et al., 2007).

Some studies have found that the $\mathrm{P} 2 \mathrm{X} 7$ receptor is expressed in renal epithelial cells (Schwiebert and Kishore, 2001; Hillman et al., 2004), although its function in non-immune cells is less clear. Under in vitro conditions, P2X7 receptors can mediate direct renal epithelial cell-fibroblast crosstalk following tubular damage; necrotic tubular cells have been shown to promote interstitial fibroblast cell death by a P2X7-dependent mechanism (Ponnusamy et al., 2011). P2X7 is also involved in polycystic kidney disease $(\mathrm{PKD})$ : in a mouse model of autosomal recessive $\mathrm{PKD}$, $\mathrm{P} 2 \mathrm{X} 7$ expression is up-regulated in CD cells as they undergo cystogenesis; in addition, $\mathrm{P} 2 \mathrm{X} 7$ antagonism can reduce cyst number, but not size, in CD suspension cultures (Hillman et al., 2002, 2004). Contrary to this, $\mathrm{P} 2 \mathrm{X} 7$ receptor blockade was shown to prevent cyst enlargement, but not frequency, in a zebrafish model of autosomal dominant PKD (Chang et al., 2011).

P2X7 expression in the kidney has also been linked to rodent models of hypertension, which is interesting, because an association study into human hypertension has shown a link between polymorphisms in the $\mathrm{P} 2 \mathrm{X} 4$ and $\mathrm{P} 2 \mathrm{X} 7$ gene region and blood pressure regulation (Palomino-Doza et al., 2008). In a renin over-expressing rat model of hypertension the expression of P2X7 is up-regulated in the glomerulus (Vonend et al., 2004). Additionally, hypertension and renal injury are attenuated in $\mathrm{P} 2 \mathrm{X}^{-/-}$mice with DOCA salt-induced hypertension, and expression of the $\mathrm{P} 2 \mathrm{X} 7$ receptor is increased in DOCA salt-treated mice vs. control mice (Ji et al., 2012b). A different study showed an attenuation of blood pressure and renal inflammation in Dahl salt-sensitive rats treated with a P2X7 antagonist (Ji et al., 2012a), suggesting that $\mathrm{P} 2 \mathrm{X} 7$ is involved in hypertension and renal injury, potentially via an inflammatory mechanism.

\section{DO P2X4 AND P2X7 INTERACT IN THE KIDNEY?}

Are the proposed interactions between P2X4 and P2X7 relevant in the kidney? Preliminary data from our laboratory suggests that genetic ablation of one may influence the renal expression of the other (Figure 2). mRNA measured in microdissected CDs and protein extracted from whole kidneys of $\mathrm{P} 2 \mathrm{X} 4^{-/-}$mice revealed that levels of $\mathrm{P} 2 \mathrm{X} 7$ were significantly reduced in $\mathrm{P} 2 \mathrm{X} 4^{-/-}$mice compared with wild-type controls. $\mathrm{P} 2 \mathrm{X} 4$ protein expression was also reduced in $\mathrm{P} 2 \mathrm{X} 7^{-/-}$mice. The $\mathrm{P} 2 \mathrm{X} 4$ protein decrease observed in $\mathrm{P} 2 \mathrm{X} 7^{-/-}$mice was confined to the membrane

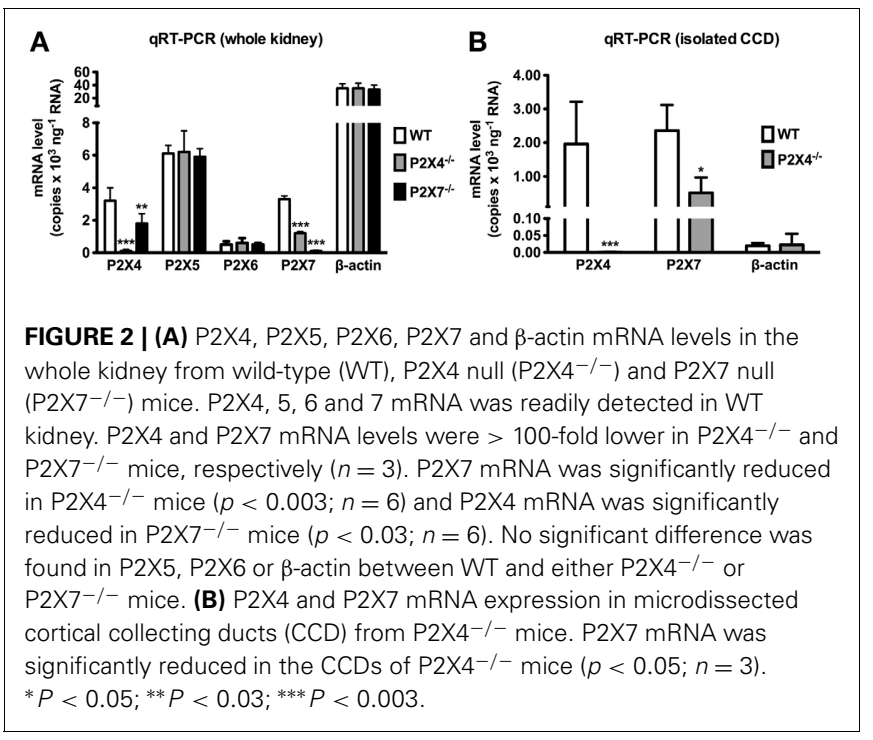

fraction, whereas the $\mathrm{P} 2 \mathrm{X} 7$ protein decrease in $\mathrm{P} 2 \mathrm{X} 4^{-/-}$mice was seen in both the membrane and cytosolic fractions. These data suggest cross-talk between P2X4 and P2X7 subunits in the kidney, and certainly in the CD. The nature of the cross-talk between P2X4 and P2X7 observed in the kidney could be one of proteinprotein interaction (i.e., a heterotrimeric assembly of P2X4 and P2X7 subunits) or of separate homotrimeric receptor coupling. Although this was not elucidated in this study, previous studies on other native and transfected systems favor the latter mechanism. Will these proposed physical interactions prove to have any functional relevance? They seem to in the immune system (Kawano et al., 2012a,b) and a similar story might hold in the kidney too.

\section{DISCUSSION AND FUTURE DIRECTIONS}

The existence of physically associated P2X subunits, whether as heterotrimers or interacting homotrimers, implies a complexity to the purinergic signaling system that may serve to adjust the regulation of physiological processes and account for unexpected pharmacological characteristics. Certainly, the altered functional and pharmacological characteristics of P2X4 and P2X7 when they are present together in native tissue and co-expressed in heterologous systems, and of $\mathrm{P} 2 \mathrm{X} 7$ when the expression of $\mathrm{P} 2 \mathrm{X} 4$ is altered, suggest that the observed interactions are functionally relevant. Moreover, our own findings that the protein levels of each receptor are altered when one is genetically ablated, as well as P2X7 RNA expression in $\mathrm{P} 2 \mathrm{X} 4^{-/-}$mice, is consistent with $\mathrm{P} 2 \mathrm{X} 4$ and $\mathrm{P} 2 \mathrm{X} 7$ functionally interacting in the kidney. However, evidence for functionally relevant P2X4 and P2X7 interactions in the kidney is circumstantial. The generation of a transgenic model that is null for both P2X4 and P2X7 would be useful in revealing the functional interdependence of these receptors, and such a model would also negate the potential of alterations in the expression of one receptor to compensate for loss of the other.

\section{ACKNOWLEDGMENTS}

We are grateful to The Wellcome Trust (Grant number WT087432MA) for funding and to Dr. Frederick Tam for providing $\mathrm{P} 2 \mathrm{X} 7^{-/-}$tissue samples. 


\section{REFERENCES}

Antonio, L. S., Stewart, A. P., Xu, X. J., Varanda, W. A., MurrellLagnado, R. D., and Edwardson, J. M. (2011). P2X4 receptors interact with both $\mathrm{P} 2 \mathrm{X} 2$ and $\mathrm{P} 2 \mathrm{X} 7$ receptors in the form of homotrimers. $B r$. J. Pharmacol. 163, 1069-1077. doi: 10.1111/j.1476-5381.2011.01303.x

Bailey, M. A., Unwin, R. J., and Shirley, D. G. (2012). P2X receptors and kidney function. WIREs Membr. Transp. Signal. 1, 503-511. doi: 10.1002/wmts.40

Barrera, N. P., Ormond, S. J., Henderson, R. M., MurrellLagnado, R. D., and Edwardson, J. M. (2005). Atomic force microscopy imaging demonstrates that $\mathrm{P} 2 \mathrm{X} 2$ receptors are trimers but that $\mathrm{P} 2 \mathrm{X} 6$ receptor subunits do not oligomerize. J. Biol. Chem. 280, 10759-10765. doi: $10.1074 /$ jbc.M412265200

Booth, J. W., Tam, F. W., and Unwin, R. J. (2012). P2 purinoceptors: renal pathophysiology and therapeutic potential. Clin. Nephrol. 78, 154-163.

Boumechache, M., Masin, M., Edwardson, J. M., Gorecki, D. C., and Murrell-Lagnado, R. (2009). Analysis of assembly and trafficking of native $\mathrm{P} 2 \mathrm{X} 4$ and $\mathrm{P} 2 \mathrm{X} 7$ receptor complexes in rodent immune cells. J. Biol. Chem. 284, 13446-13454. doi: 10.1074/jbc.M901255200

Brone, B., Moechars, D., Marrannes, R., Mercken, M., and Meert, T. (2007). P2X currents in peritoneal macrophages of wild type and P2X4 -/- mice. Immunol. Lett. 113, 83-89. doi: 10.1016/j.imlet.2007.07.015

Casas-Pruneda, G., Reyes, J. P., PerezFlores, G., Perez-Cornejo, P., and Arreola, J. (2009). Functional interactions between P2X4 and $\mathrm{P} 2 \mathrm{X} 7$ receptors from mouse salivary epithelia. J. Physiol. 587, 2887-2901. doi: 10.1113/jphysiol.2008.167395

Chang, M. Y., Lu, J. K., Tian, Y. C., Chen, Y. C., Hung, C. C., Huang, Y. H., et al. (2011). Inhibition of the P2X7 receptor reduces cystogenesis in PKD. J. Am. Soc. Nephrol. 22, 1696-1706. doi: 10.1681/ASN.2010070728

Compan, V., Ulmann, L., Stelmashenko, O., Chemin, J., Chaumont, S., and Rassendren, F. (2012). P2X2 and P2X5 subunits define a new heteromeric receptor with $\mathrm{P} 2 \mathrm{X} 7$-like properties. J. Neurosci. 32, 4284-4296. doi: 10.1523/JNEUROSCI.6332-11.2012

Goncalves, R. G., Gabrich, L., Rosario, A. Jr., Takiya, C. M., Ferreira, M. L., Chiarini, L. B., et al. (2006). The role of purinergic $\mathrm{P} 2 \mathrm{X} 7$ receptors in the inflammation and fibrosis of unilateral ureteral obstruction in mice. Kidney Int. 70, 1599-1606. doi: 10.1038/sj.ki.5001804

Gorelik, J., Zhang, Y., Sanchez, D., Shevchuk, A., Frolenkov, G., Lab, M., et al. (2005). Aldosterone acts via an ATP autocrine/paracrine system: the Edelman ATP hypothesis revisited. Proc. Natl. Acad. Sci. U.S.A. 102, 15000-15005. doi: 10.1073/pnas.0507008102

Guo, C., Masin, M., Qureshi, O.S., and Murrell-Lagnado, R. D. (2007). Evidence for functional $\mathrm{P} 2 \mathrm{X} 4 / \mathrm{P} 2 \mathrm{X} 7$ heteromeric receptors. Mol. Pharmacol. 72, 1447-1456. doi: 10.1124/mol.107.035980

Hillman, K. A., Johnson, T. M., Winyard, P. J., Burnstock, G., Unwin, R. J., and Woolf, A. S. (2002). P2X(7) receptors are expressed during mouse nephrogenesis and in collecting duct cysts of the cpk/cpk mouse. Exp. Nephrol. 10,34-42. doi: 10.1159/000049896

Hillman, K. A., Woolf, A. S., Johnson, T. M., Wade, A., Unwin, R. J., and Winyard, P. J. (2004). The P2X7 ATP receptor modulates renal cyst development in vitro. Biochem. Biophys. Res. Commun. 322, 434-439. doi: 10.1016/j.bbrc.2004.07.148

Inscho, E. W., Cook, A. K., Imig, J. D., Vial, C., and Evans, R. J. (2004). Renal autoregulation in P2X1 knockout mice. Acta Physiol. Scand. 181, 445-453. doi: 10.1111/j.1365-201X.2004.01317.x

Ji, X., Naito, Y., Hirokawa, G., Weng, H., Hiura, Y., Takahashi, R., et al. (2012a). P2X(7) receptor antagonism attenuates the hypertension and renal injury in Dahl saltsensitive rats. Hypertens. Res. 35, 173-179.

Ji, X., Naito, Y., Weng, H., Endo, K., Ma, X., and Iwai, N. (2012b). P2X7 deficiency attenuates hypertension and renal injury in deoxycorticosterone acetate-salt hypertension. Am. J. Physiol. Renal Physiol. 303, F1207-F1215. doi: 10.1152/ajprenal.00051.2012

Kawano, A., Tsukimoto, M., Mori, D., Noguchi, T., Harada, H., Takenouchi, T., et al. (2012a). Regulation of P2X7-dependent inflammatory functions by $\mathrm{P} 2 \mathrm{X} 4$ receptor in mouse macrophages. Biochem. Biophys. Res. Commun. 420, 102-107. doi: 10.1016/j.bbrc.2012.02.122

Kawano, A., Tsukimoto, M., Noguchi, T., Hotta, N., Harada, H., Takenouchi, T., et al. (2012b). Involvement of P2X4 receptor in $\mathrm{P} 2 \mathrm{X} 7$ receptordependent cell death of mouse macrophages. Biochem. Biophys.
Res. Commun. 419, 374-380. doi: 10.1016/j.bbrc.2012.01.156

Kawate, T., Michel, J. C., Birdsong, W. T., and Gouaux, E. (2009) Crystal structure of the ATP-gated $\mathrm{P} 2 \mathrm{X}(4)$ ion channel in the closed state. Nature 460, 592-598. doi: 10.1038/nature08198

Khakh, B. S., Bao, X. R., Labarca, C. and Lester, H. A. (1999). Neuronal P2X transmitter-gated cation channels change their ion selectivity in seconds. Nat. Neurosci. 2, 322-330. doi: $10.1038 / 7233$

King, B. F., Townsend-Nicholson, A. Wildman, S. S., Thomas, T., Spyer, K. M., and Burnstock, G. (2000). Coexpression of rat $\mathrm{P} 2 \mathrm{X} 2$ and P2X6 subunits in Xenopus oocytes. J. Neurosci. 20, 4871-4877.

Korngreen, A., Ma, W., Priel, Z., and Silberberg, S. D. (1998). Extracellular ATP directly gates a cation-selective channel in rabbit airway ciliated epithelial cells. J. Physiol. 508(Pt 3), 703-720. doi: $\quad 10.1111 /$ j.1469-7793.1998. 703bp.x

Lewis, C., Neidhart, S., Holy, C., North R. A., Buell, G., and Surprenant, A. (1995). Coexpression of P2X2 and $\mathrm{P} 2 \mathrm{X} 3$ receptor subunits can account for ATP-gated currents in sensory neurons. Nature 377, 432-435. doi $10.1038 / 377432 \mathrm{a} 0$

Lifton, R. P., Gharavi, A. G., and Geller, D. S. (2001). Molecular mechanisms of human hypertension. Cell 104, 545-556. doi: 10.1016/S00928674(01)00241-0

Ma, W., Korngreen, A., Uzlaner, N., Priel, Z., and Silberberg, S.D. (1999). Extracellular sodium regulates airway ciliary motility by inhibiting a P2X receptor. Nature 400, 894-897. doi: 10.1038/23743

Ma, W., Korngreen, A., Weil, S., Cohen, E. B., Priel, A., Kuzin L., et al. (2006). Pore properties and pharmacological features of the P2X receptor channel in airway ciliated cells. J. Physiol. 571, 503-517. doi: 10.1113/jphysiol. 2005.103408

Malnic, G., Klose, R. M., and Giebisch, G. (1966). Micropuncture study of distal tubular potassium and sodium transport in rat nephron. Am. J. Physiol. 211, 529-547.

Marques, R. D., de Bruijn, P. I., Sorensen, M. V., Bleich, M., Praetorius, H. A., and Leipziger, J. (2012). Basolateral P2X receptors mediate inhibition of $\mathrm{NaCl}$ transport in mouse medullary thick ascending limb (mTAL). Am. J. Physiol. Renal Physiol. 302, F487-F494. doi: 10.1152/ajprenal.00570.2011
McCoy, D. E., Taylor, A. L., Kudlow, B. A., Karlson, K., Slattery, M. J., Schwiebert, L. M., et al. (1999). Nucleotides regulate $\mathrm{NaCl}$ transport in mIMCD-K2 cells via $\mathrm{P} 2 \mathrm{X}$ and $\mathrm{P} 2 \mathrm{Y}$ purinergic receptors. Am. J. Physiol. 277, F552-F559.

Murrell-Lagnado, R. D., and Qureshi, O. S. (2008). Assembly and trafficking of P2X purinergic receptors (Review). Mol. Membr. Biol. 25, 321-331. doi: $10.1080 / 09687680802050385$

Nicke, A. (2008). Homotrimeric complexes are the dominant assembly state of native $\mathrm{P} 2 \mathrm{X} 7$ subunits. Biochem. Biophys. Res. Commun. 377, 803-808. doi: 10.1016/j.bbrc.2008.10.042

Nicke, A., Baumert, H. G., Rettinger, J., Eichele, A., Lambrecht, G., Mutschler, E., et al. (1998). P2X1 and P2X3 receptors form stable trimers: a novel structural motif of ligand-gated ion channels. EMBO J. 17, 3016-3028. doi: 10.1093/emboj/17.11.3016

North, R. A. (2002). Molecular physiology of P2X receptors. Physiol. Rev. 82, 1013-1067.

North, R. A., and Surprenant, A. (2000). Pharmacology of cloned P2X receptors. Annu. Rev. Pharmacol. Toxicol. 40, 563-580. doi: 10.1146/annurev.pharmtox.40. 1.563

Odgaard, E., Praetorius, H. A., and Leipziger, J. (2009). AVPstimulated nucleotide secretion in perfused mouse medullary thick ascending limb and cortical collecting duct. Am. J. Physiol. Renal Physiol. 297, F341-F349. doi: 10.1152/ajprenal.00190.2009

Palomino-Doza, J., Rahman, T. J., Avery, P. J., Mayosi, B. M., Farrall, M., Watkins, H., et al. (2008). Ambulatory blood pressure is associated with polymorphic variation in $\mathrm{P} 2 \mathrm{X}$ receptor genes. Hypertension 52, 980-985. doi: 10.1161/HYPERTENSIONAHA. 108.113282

Pelegrin, P. (2011). Many ways to dilate the $\mathrm{P} 2 \mathrm{X} 7$ receptor pore. $\mathrm{Br}$. J. Pharmacol. 163, 908-911. doi: 10.1111/j.1476-5381.2011.01325.x

Pochynyuk, O., Bugaj, V., Rieg, T., Insel, P. A., Mironova, E., Vallon, V., et al. (2008). Paracrine regulation of the epithelial $\mathrm{Na}+$ channel in the mammalian collecting duct by purinergic P2Y2 receptor tone. J. Biol. Chem. 283, 36599-36607. doi: 10.1074/jbc. M807129200

Pochynyuk, O., Rieg, T., Bugaj, V., Schroth, J., Fridman, A., Boss, G. R., et al. (2010). Dietary Na+ inhibits 
the open probability of the epithelial sodium channel in the kidney by enhancing apical P2Y2-receptor tone. FASEB J. 24, 2056-2065. doi: 10.1096/fj.09-151506

Ponnusamy, M., Ma, L., Gong, R., Pang, M., Chin, Y. E., and Zhuang, S. (2011). P2X7 receptors mediate deleterious renal epithelial-fibroblast cross talk. Am. J. Physiol. Renal Physiol. 300, F62-F70. doi: 10.1152/ajprenal. 00473.2010

Praetorius, H. A., and Leipziger, J. (2010). Intrarenal purinergic signaling in the control of renal tubular transport. Annu. Rev. Physiol. 72, 377-393. doi: 10.1146/annurevphysiol-021909-135825

Rieg, T., Bundey, R. A., Chen, Y., Deschenes, G., Junger, W., Insel, P. A., et al. (2007). Mice lacking P2Y2 receptors have salt-resistant hypertension and facilitated renal $\mathrm{Na}+$ and water reabsorption. FASEB J. 21, 3717-3726. doi: 10.1096/fj.078807 com

Sakaki, H., Fujiwaki, T., Tsukimoto, M., Kawano, A., Harada, H., and Kojima, S. (2013). P2X4 receptor regulates $\mathrm{P} 2 \mathrm{X} 7$ receptor-dependent IL-1beta and IL-18 release in mouse bone marrow-derived dendritic cells. Biochem. Biophys. Res. Commun. 432, 406-411. doi: 10.1016/j.bbrc.2013.01.135

Schwiebert, E. M., and Kishore, B. K. (2001). Extracellular nucleotide signaling along the renal epithelium. Am. J. Physiol. Renal Physiol. 280, F945-F963.

Shirley, D. G., Vekaria, R. M., and Sevigny, J. (2009). Ectonucleotidases in the kidney. Purinergic Signal. 5, 501-511. doi: 10.1007/s11302-009-9152-4

Sim, J. A., Chaumont, S., Jo, J., Ulmann, L., Young, M. T., Cho, K., et al. (2006). Altered hippocampal synaptic potentiation in P2X4 knock-out mice. J. Neurosci. 26, 9006-9009. doi: 10.1523/JNEUROSCI.2370-06.2006

Soto, F., Garcia-Guzman, M., GomezHernandez, J. M., Hollmann, M., Karschin, C., and Stuhmer, W. (1996). P2X4: an ATP-activated ionotropic receptor cloned from rat brain. Proc. Natl. Acad.
Sci. U.S.A. 93, 3684-3688. doi: 10.1073/pnas.93.8.3684

Stockand, J. D., Mironova, E., Bugaj, V., Rieg, T., Insel, P. A., Vallon, V., et al. (2010). Purinergic inhibition of $\mathrm{ENaC}$ produces aldosterone escape. J. Am. Soc. Nephrol. 21, 1903-1911. doi: 10.1681/ASN. 2010040377

Surprenant, A., and North, R. A. (2009). Signaling at purinergic P2X receptors. Annu. Rev. Physiol. 71, 333-359. doi: 10.1146/annurev.physiol.70.113006. 100630

Taylor, S. R., Turner, C. M., Elliott, J. I., McDaid, J., Hewitt, R., Smith, J., et al. (2009). P2X7 deficiency attenuates renal injury in experimental glomerulonephritis. J. Am. Soc. Nephrol. 20, 1275-1281. doi: 10.1681/ASN.2008060559

Torres, G. E., Egan, T. M., and Voigt, M. M. (1999). Hetero-oligomeric assembly of $\mathrm{P} 2 \mathrm{X}$ receptor subunits. Specificities exist with regard to possible partners. J. Biol. Chem. 274, 6653-6659. doi: 10.1074/jbc.274.10.6653

Tsuda, M., Kuboyama, K., Inoue, T., Nagata, K., Tozaki-Saitoh, H., and Inoue, K. (2009). Behavioral phenotypes of mice lacking purinergic $\mathrm{P} 2 \mathrm{X} 4$ receptors in acute and chronic pain assays. Mol. Pain 5:28. doi: 10.1186/1744-8069-5-28

Turner, C. M., Tam, F. W., Lai, P. C., Tarzi, R. M., Burnstock, G., Pusey, C. D., et al. (2007). Increased expression of the pro-apoptotic ATP-sensitive P2X7 receptor in experimental and human glomerulonephritis. Nephrol. Dial. Transplant. 22, 386-395.

Turner, C. M., Vonend, O., Chan, C., Burnstock, G., and Unwin, R. J. (2003). The pattern of distribution of selected ATP-sensitive P2 receptor subtypes in normal rat kidney: an immunohistological study. Cells Tissues, Organs 175, 105-117. doi: 10.1159/000073754

Ulmann, L., Hirbec, H., and Rassendren, F. (2010). P2X4 receptors mediate PGE2 release by tissue-resident macrophages and initiate inflammatory pain. EMBO J. 29, 2290-2300. doi: 10.1038/emboj.2010.126
Vallon, V. (2008). P2 receptors in the regulation of renal transport mechanisms. Am. J. Physiol. Renal Physiol. 294, F10-F27. doi: 10.1152/ajprenal.00432.2007

Vallon, V., and Rieg, T. (2011). Regulation of renal $\mathrm{NaCl}$ and water transport by the ATP/UTP/P2Y2 receptor system. Am. J. Physiol. Renal Physiol. 301, F463-F475. doi: 10.1152/ajprenal.00236.2011

Vekaria, R. M., Unwin, R. J., and Shirley, D. G. (2006). Intraluminal ATP concentrations in rat renal tubules. J. Am. Soc. Nephrol. 17, 1841-1847. doi: 10.1681/ASN.2005111171

Virginio, C., MacKenzie, A., Rassendren, F. A., North, R. A., and Surprenant, A. (1999). Pore dilation of neuronal $\mathrm{P} 2 \mathrm{X}$ receptor channels. Nat. Neurosci. 2, 315-321. doi: 10.1038/7225

Vonend, O., Turner, C. M., Chan, C. M., Loesch, A., Dell'Anna, G. C. Srai, K. S., et al. (2004). Glomerular expression of the ATP-sensitive P2X receptor in diabetic and hypertensive rat models. Kidney Int. 66, 157-166. doi: 10.1111/j.15231755.2004.00717.x

von Kugelgen, I., and Harden, T. K (2011). Molecular pharmacology, physiology, and structure of the P2Y receptors. Adv. Pharmacol. 61, 373-415. doi: 10.1016/B978-0-12385526-8.00012-6

Weinhold, K., Krause-Buchholz, U., Rodel, G., Kasper, M., and Barth, K. (2010). Interaction and interrelation of P2X7 and P2X4 receptor complexes in mouse lung epithelial cells. Cell. Mol. Life Sci. 67, 2631-2642. doi: 10.1007/s00018-010-0355-1

Wildman, S. S., Marks, J., Churchill, L. J., Peppiatt, C. M., Chraibi, A., Shirley, D. G., et al. (2005). Regulatory interdependence of cloned epithelial $\mathrm{Na}+$ channels and P2X receptors. J. Am. Soc. Nephrol. 16, 2586-2597. doi: 10.1681/ASN.2005020130

Wildman, S. S., Marks, J., Turner, C. M., Yew-Booth, L., PeppiattWildman, C. M., King, B. F., et al. (2008). Sodium-dependent regulation of renal amiloride-sensitive currents by apical P2 receptors.
J. Am. Soc. Nephrol. 19, 731-742. doi: 10.1681/ASN.2007040443

Yamamoto, K., Sokabe, T., Matsumoto, T., Yoshimura, K., Shibata, M., Ohura, N., et al. (2006). Impaired flow-dependent control of vascular tone and remodeling in P2X4-deficient mice. Nat. Med. 12, 133-137. doi: 10.1038/nm1338

Zhang, Y., Listhrop, R., Ecelbarger, C. M., and Kishore, B. K. (2011). Renal sodium transporter/channel expression and sodium excretion in $\mathrm{P} 2 \mathrm{Y} 2$ receptor knockout mice fed a high- $\mathrm{NaCl}$ diet with/without aldosterone infusion. Am. J. Physiol. Renal Physiol. 300, F657-F668. doi: 10.1152/ajprenal.00549.2010

Zhang, Y., Sanchez, D., Gorelik, J., Klenerman, D., Lab, M., Edwards, C., et al. (2007). Basolateral $\mathrm{P} 2 \mathrm{X} 4$-like receptors regulate the extracellular ATP-stimulated epithelial $\mathrm{Na}+$ channel activity in renal epithelia. Am. J. Physiol. Renal Physiol. 292, F1734-F1740. doi: 10.1152/ajprenal.00382.2006

Conflict of Interest Statement: The authors declare that the research was conducted in the absence of any commercial or financial relationships that could be construed as a potential conflict of interest.

Received: 15 May 2013; accepted: 27 July 2013; published online: 15 August 2013. Citation: Craigie E, Birch RE, Unwin $R J$ and Wildman SS (2013) The relationship between P2X4 and P2X7: a physiologically important interaction? Front. Physiol. 4:216. doi: 10.3389/fphys. 2013.00216

This article was submitted to Frontiers in Renal and Epithelial Physiology, a specialty of Frontiers in Physiology. Copyright (c) 2013 Craigie, Birch, Unwin and Wildman. This is an openaccess article distributed under the terms of the Creative Commons Attribution License (CC BY). The use, distribution or reproduction in other forums is permitted, provided the original author(s) or licensor are credited and that the original publication in this journal is cited, in accordance with accepted academic practice. No use, distribution or reproduction is permitted which does not comply with these terms. 